\title{
Collaborative governance towards cities sustainability transition
}

\author{
Governança colaborativa para a transição da sustentabilidade nas cidades
}

Diego de Melo Conti[a] $\odot$, Arnoldo José de Hoyos Guevara[b] ${ }^{\circledR}$, Harald Heinrichs[c] $(\mathbb{C}$,

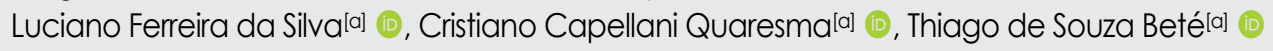

[a] Universidade Nove de Julho (Uninove), São Paulo, SP, Brasil

[b] Pontifícia Universidade Católica de São Paulo (PUC-SP), São Paulo, SP, Brasil

[c] Leuphana Universität Lüneburg, Lüneburg, Lower Saxony, Germany

How to cite: Conti, D. M., Guevara, A. J. H., Heinrichs, H., Silva, L. F., Quaresma, C. C., \& Beté, T. S. (2019). Collaborative governance towards cities sustainability transition. urbe. Revista Brasileira de Gestão Urbana, 11, e20190046. https://doi.org/10.1590/2175-3369.011.e20190046

\section{Abstract}

Cities and their constant growth have a crucial role in global sustainable development. The objective of this article is to present a conceptual framework of collaborative governance for the shaping of sustainable cities. The adoption of the multiple case study (5) method allowed understanding the reality of the cities of Copenhagen (Denmark), Amsterdam (Netherlands), London (England), Hamburg (Germany) and Barcelona (Spain). Sources of evidence were collected through in-depth interviews, documents, and observation, plus the data analysis was performed by using the NVivo software. For that, exploratory-descriptive research was conducted with the use of a qualitative research approach. The results exhibit strategies, benefits, risks, and limits inherent to collaborative governance systems in the cities and bring contributions to the development of the governance theory.

Keywords: Collaborative governance. Sustainability. Sustainable cities. Sustainable governance.

\section{Resumo}

As cidades e seu constante crescimento têm um papel crucial no desenvolvimento sustentável global. O objetivo deste artigo é apresentar uma estrutura conceitual de governança colaborativa para a formação de cidades sustentáveis. A adoção do método de estudo de casos múltiplos (5) permitiu compreender a realidade das cidades de Copenhague (Dinamarca), Amsterdã (Holanda), Londres (Inglaterra), Hamburgo (Alemanha) e Barcelona (Espanha). As fontes de evidências foram coletadas por meio de entrevistas em profundidade, documentos e observação, sendo que a análise de dados foi realizada utilizando o software NVivo. Para tanto, realizou-se pesquisa exploratório-descritiva com abordagem de pesquisa qualitativa.

DMC is doctor in Business Administration, e-mail: diegoconti@uol.com.br

AJHG is doctor in Statistics, e-mail: arnoldodehoyos@yahoo.com.br

HH is doctor in Sociology, e-mail: hheinric@leuphana.de

LFS is doctor in Business Administration, e-mail: lf_silvabr@yahoo.com.br

CCQ is doctor in Geography, e-mail: quaresma.cristiano@gmail.com

TSB is master student in Smart and Sustainable Cities, e-mail: bete.souza.thiago@gmail.com 
Os resultados apresentam estratégias, benefícios, riscos e limites inerentes aos sistemas de governança colaborativa nas cidades e trazem contribuições para o desenvolvimento da teoria da governança.

Palavras-chave: Governança colaborativa. Sustentabilidade. Cidades sustentáveis. Governança sustentável.

\section{Introduction}

Cities have a crucial role to play for the planet's sustainable development, not only for being the large cluster of human activities, its demographic characteristics and infrastructure resulting in an overuse use of ecological resources, but mainly for its political-economic importance and its ability to engage people and influence actions towards sustainability (Dobbs \& Remes, 2013).

The cities' growth is an indissociable tendency of current global developments and this subject requires attention to the construction of governance models capable to deal with the complexity of urbanized societies and its challenges to sustainability. In this sense, innovations emerge to promote sustainable development (Schwab, 2017).

Sustainability in cities expresses the idea of development with quality of life and essential conditions for liveability (Kahn, 2013). This means managing resources (economic, social, ecological) properly, building plans and achieving results, which is defined here as governance. Ruzzarin \& Siminovschi (2010) argue that the different governance strands are related to the ideas of risk reduction and the creation of transparent policies. Ansell \& Gash (2007) reinforce the relevance of collaborative governance systems to correct failures and reduce the costs of implementing public policies.

Collaborative governance has been adopted by a number of cities around the world as a solution to local problems (Blanco, 2013; Healey, 2015), highlighting its important role in preserving the environment and reducing ecological scarcity, in promoting social justice and equality, in creating longterm plans and holistic views, in transparency and better use of public resources, and in reconciling economic interests for the transition to a low carbon economy. In this context, it can be said that this is a multilevel and multisectoral theme (Bulkeley \& Betsill, 2005; Francis \& Feiock, 2011; Gorissen et al., 2016).

Governance addresses the capacity for articulation and cooperation between different stakeholders to discuss issues of mutual interest (Li et al., 2016). The World Bank Group (1992) defined governance as the way in which power is practiced in the administration of resources for the development and the capacity of governments to plan, formulate and program policies. This means that governance also expresses the notion of the exercise of power or how the authority model of a government is realized.

Miranda \& Amaral (2011) report on their work that the term governance has spread in several areas of knowledge. It can be affirmed that the governance subject is adopted in the public and/or private management field (Elkington, 2006; Gupta et al., 2015; Boström, et al., 2015; Filatotchev \& Wright, 2017).

The literature shows that governance models can boost governments to a new way of doing politics, making cities increasingly democratic (Matias-Pereira, 2010; McCormick et al., 2013). Dallabrida (2015) evidenced the existence of four analytical aspects that frequently appear in the models and literature of public governance: a) power relations between stakeholders; b) mechanisms in a decision-making process; c) instruments for articulating and coordinating public policies; d) impacts and results of policies arising from collaborative governance processes.

Streit \& Klering (2004) also point out four common characteristics, which were defined based on fifteen different governance concepts: a) existence of regulatory structures and mechanisms; b) emphasis on the process of interaction itself, rather than on its own results; c) networking performance; d) presence of goals and common action guides. In this way, it can be said that the establishment of a democratic governance system can be understood as a fundamental pillar for an efficient, egalitarian and transparent city (Glaeser \& Joshi-Ghani, 2013). 
In this perspective of rethinking the governance model of cities, Ronconi (2011) argues that collaborative governance is a kind of governmental institutional arrangement, which articulates different dimensions of society through the establishment of plans and partnerships. This new model emerges as an important milestone for the operationalization of the principles of democracy since it articulates and reinforces the participation of social actors in the processes of public policy formulation, deliberation, and decision.

Based on these insights it can be determined, that collaboration in local governance is considered to be a fundamental element for sustainable development, since it enhances the democratic aspects of a society, allows all citizens to participate in the of governance processes and policy-making, establishing principles for the construction of a culture of peace and city for the people (De Oliveira et al., 2013; Bryson et al., 2014).

Initiatives and mechanisms that articulate different stakeholders in collaborative governance systems have brought important advances towards sustainable development, since participatory models, especially for the solution of local problems, present greater adherence and stimulation for stakeholder engagement, as well as good plans and greater efficiency in the implementation of projects (Ronconi, 2011; Hawkins \& Wang, 2012).

It is emphasized that collaborative governance in cities can develop solutions for complex global problems such as the negative effects of climate change (ONU-Habitat, 2011; Kapucu, 2015; Eldridge et al., 2018). This is because it helps social changes to happen through political engagement.

The literature on collaborative governance has shown that the management of a more sustainable city is built on the articulation and exchange of different actors in collaboration processes. It is important to note that in a collaborative process one must consider the participation of representatives of civil society, as well as the political and technical-administrative stakeholders (Kissler \& Heidemann, 2006; Ronconi, 2011; Marcaletti \& Riniolo, 2015).

As a contribution, this research aimed to present a conceptual framework of collaborative governance through qualitative research based on a multiple case study method, providing further knowledge for the collaborative governance theory and for the development of sustainable cities.

\section{Collaborative governance}

The involvement of stakeholders in local affairs has gained space in cities governance discussions (Elkington, 2006; Gupta et al., 2015). In dealing with this involvement it is necessary to understand the functioning of stakeholder interaction in governance systems (Fukuyama, 2013). Wachhaus (2013) argues that governance determines who has influence, who decides, and how decision-makers are held accountable. Therefore, the greater the participation of diverse stakeholders in the planning and the decision making, the greater the evidence of collaborative governance.

The collaborative governance gained ground in Europe around the 2000s, with a central focus on shared management (Ansell \& Gash, 2007; Ronconi, 2011). As Emerson et al. (2011) stressed, the collaborative governance follow six important criteria: a) the forum is initiated by public agencies or institutions; b) participants in the forum include nonstate actors; c) participants engage directly in decision making and are not merely "consulted" by public agencies; d) the forum is formally organized and meets collectively; e) the forum aims to make decisions by consensus (even if consensus is not achieved in practice), and; f) the focus of collaboration is on public policy or public management.

In this context, the convergence of ideas places governance as a key factor in strengthening democracy and citizenship in a city, making the role of individuals and organized civil society, crucial for city management (Ansell \& Gash, 2007). Corroborating with these ideas, it can be said that the collaborative governance broadens the management to the participation of diverse actors and allows social control under the political actions, being this a political model able to create the necessary environment for the cooperation and social participation (Ronconi, 2011). 
This makes collaborative democracy go beyond the boundaries of representative democracy, which makes collaborative governance an important strategy for managing sustainable cities (Challies et al., 2016; Hamilton \& Lubell, 2017). Wargent \& Parker (2018) emphasize that principles of collaborative governance, based on the role and leadership of citizens, ground the idea of collaborative democracy. In this sense, Bartoletti \& Faccioli (2016) argue that democracy must be inclusive, allowing citizens to participate and collaborate. Therefore, Helms (2016) reports that representative democracy, which is played by political agents, is experiencing a crisis and that new governance models are needed.

The authors Van De Meene et al. (2011), Smith \& Wiek (2012), and Emerson \& Nabatchi (2015) highlight that collaborative governance has been the management tool adopted by several cities in order to empower the path to sustainable development. As a result, collaborative governance systems make citizens become the protagonists in the local development process (Ansell \& Gash, 2007; Emerson et al., 2011). This can happen for a variety of reasons and collaborative decisions must formally require consensus, even if it takes time and lengthy negotiations (Hawkins \& Wang, 2012). The importance of consensus orientation is given by the fact that minority opinion cannot be disregarded.

It is important to say that the success of collaborative governance depends not only on the strategy of including non-governmental actors in the management of a city but also of a mobilized society. This happens because the engagement and mobilization of several actors can directly impact social transformation and sustainability issues (Emerson et al., 2011; Bryson et al., 2014; Gupta et al., 2015).

Kissler \& Heidemann (2006) stress that different models of collaborative governance allow the use of several other tools, such as surveys, focus groups, referendums, expert's networks, among others. Furthermore, Shark (2012) and Skelcher et al. (2013) argue that the combination of face-to-face participatory governance tools coupled with participatory digital platforms opens the way for the creation of hybrid governance tools.

Despite all the benefits presented so far, Kissler \& Heidemann (2006) and Hawkins \& Wang (2012) argue that collaborative governance systems have vulnerabilities, which can impose risks for this model. According to this literature, an example of this situation can be perceived in artificial participatory governance processes that only serve the interests of groups with more power, generating an imbalance of forces and compromising the interest of the collective.

Ansell \& Gash (2007) describe that systems of collaborative governance must follow a set of rules. The authors demonstrate some fundamental principles, such as the importance to maintain the independence and interdependence of stakeholders in negotiation processes; the standing to establish transparent rules and bases for the negotiation processes; and the necessity to create an environment of interaction based on trust and collaborative attitudes.

Hawkins \& Wang (2012) emphasize that the creation of collaborative structures must provide conditions for participation through an environment capable of generating results for local sustainable development, effectively reducing conflicts and building consensus for sustainable and long-term actions.

Cities must build a model of collaborative governance that provides new opportunities for public managers as well as citizens, enabling access, interaction, and integration to ensure the well-being and the creation of liveable cities. Thus, cities should develop strategies with principles of good governance, like negotiation, transparency, communication, trust and cooperation between stakeholders (Ronconi, 2011; Fukuyama, 2013; Li \& de Jong, 2017).

Fukuyama (2013) argues that transparency is crucial for the proper use of public resources and for clarity in decision-making. Furthermore, transparency is a key element for civil society organizations to monitor government activities. This optimizes accountability systems and enables the construction of indicators to monitor the goals and plans of a government (Li \& de Jong, 2017; Jannuzzi, 2017).

This model of city management is central to good governance, as it establishes long-term plans that go beyond political terms. In this sense, Frey (2004) argues that spaces for interactive discussion and group work should be created in order to develop long-term strategies and to contemplate the widest variety of stakeholders, aiming to build bridges of understanding between the different actors and a vision of the future (Li \& de Jong, 2017). 
Krause (2016) stresses that long-term and sustainable plans could be established through citypartnerships in regional levels, as soon as a network or regional pact is created looking to the future, establishing alliances for integrated solutions. As an example, there are several city networks at a national or international level, such as the Sustainable Cities Program in Brazil (Duarte, 2015) or C40 or ICLEI (Yi et al., 2017).

In this theoretical research, several tools proved to develop collaborative governance, being the city's role to define the best tool and strategy to achieve a certain result. It has been shown that numerous benefits can arise from a local participatory model, being necessary to work transparently and technically to minimize risks and threats inherent to collaborative governance systems. In addition, a collaborative governance framework is an important tool to establish a city's long-term plan.

\section{Methodological procedures}

This research followed an exploratory-descriptive perspective adopting qualitative research methods in order to deepen and to signify the researched phenomenon (Miles \& Huberman 1984; Marshall \& Rossman, 2006), namely the collaborative governance in sustainable cities. Thus, the methodological choices were suited to understand the collaborative governance model of the cities of Copenhagen (Denmark), Amsterdam (Netherlands), London (England), Hamburg (Germany) and Barcelona (Spain).

The multiple case study was adopted to oriented of research through data -collection procedures in order to guarantee the triangulation of the various evidence sources (Eisenhardt, 1989; Yin, 2005). In order to guarantee the quality and validity in this research, we sought a reasoned description of the procedures and concepts of qualitative approach (Kirk \& Miller, 1986).

It is worth mentioning that the collection and analytical procedures applied in this research followed a data-driven perspective that uses the data collected in the field to generate categories of analysis in order to take advantage of all the sources of evidence (Charmaz, 2006; Saldaña, 2016).

Regarding the unit of analysis, the choice of the 5 cities of this study was based in: a) politicaleconomic importance; b) population size, with a minimum cut of 500,000 inhabitants and, in the case of London, as a representation of a megacity; c) geographical differences regarding the influence of rivers and seas, taking a significant look at the theme of climate change; d) sustainability policies and networks.

The procedures for data collection were through in-depth interviews. For this study, we considered 30 interviews, six of each analyzed city. In order to protect the identity of the interviewees, they will be presented in the results by the letter "I" followed by a number, for example, "I11". In addition, it is important to emphasize that the interviewed were intentionally defined and divided into four types, as shown in Table 1, which allowed a systemic understanding of the analyzed phenomenon.

Table 1 - Characteristics of the interviewed

\begin{tabular}{|c|c|}
\hline Type of Respondent & Description \\
\hline Public Administration & $\begin{array}{l}\text { Technician of the local administration in a leadership position related to the area of } \\
\text { governance or sustainability. }\end{array}$ \\
\hline Politician & Politician, member of the sustainability committee (or similar) of the local parliament. \\
\hline Industry and Commerce & $\begin{array}{c}\text { Member of an industrial or commercial association related to the board or } \\
\text { department of governance or sustainability. }\end{array}$ \\
\hline Third sector & $\begin{array}{c}\begin{array}{c}\text { Member of a non-governmental organization or expressive movement linked to the } \\
\text { city's sustainability. }\end{array}\end{array}$ \\
\hline
\end{tabular}

Source: Authors (2019).

The interviews followed a single protocol, starting by taking notes of the interviewee's personal data in a specific way and then explaining the objectives and ethical procedures (Marshall \& Rossman, 2006; Creswell, 2013). Next, the interview was conducted using a script with pre-defined and open questions, accompanied by the recording of the conversation for later transcription. In addition, the interviewees 
were observed by the researchers, which allowed for a deeper analysis of feelings and reactions, admitting the note-taking (Flick, 2008).

The study also used document analysis and direct observation of cities with photographic records to check sustainability policies and collaborative governance results (Lakatos \& Marconi, 1992). This attention allows guaranteeing reliability and validity of research with the triangulation of evidence sources (Yin, 2005; Creswell, 2013).

For the data treatment, the categorization of the obtained data was carried out for a comparative analysis of the emergent findings in the different cases (Flick, 2008; Charmaz, 2006; Saldaña, 2016). The software Nvivo 9 was used for the data organization and later analysis of the categories and subcategories extracted from the literature review.

Therefore, when analyzing the research corpus, i.e., a set of evidence that constituted the hermeneutical unit, it was possible to rescue with the aid of the software the arguments necessary to reach the results of this research. This process took place through the search for patterns evidenced in the theoretical categories and in the empirical evidence, which allowed the elaboration of a conceptual framework of collaborative governance for sustainability.

\section{Results}

\section{Analyzed cities}

The research was conducted in five major European cities - Copenhagen, Amsterdam, London, Hamburg, and Barcelona, which have a high performance in sustainability practices, long-term public policies and collaborative governance systems (Copenhagen, 2014; Amsterdam, 2015; London, 2015; Hamburg, 2016; Barcelona, 2015). In Figure 1, a map is presented and it highlights the location of the performed case studies. It is important to stress that for the map creation, the ArcMap 10.1 software was used and, after the acquisition of the georeferenced map of Europe, a point-type layer was created for the georeferencing of the cities. 


\section{COLLABORATIVE GOVERNANCE IN EUROPEAN CITIES}

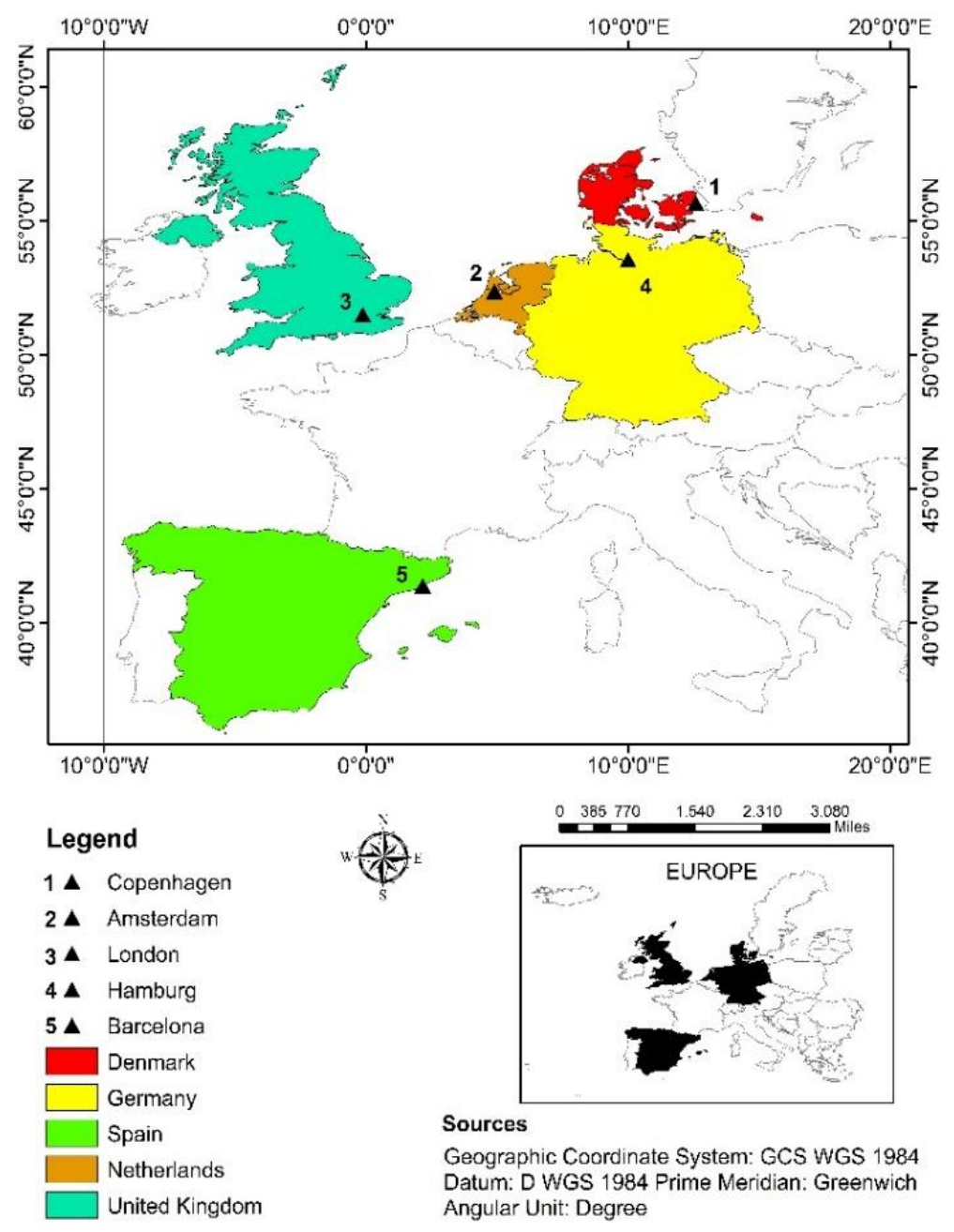

Figure 1 - Map of analyzed cities. Source: Authors (2018).

Figure 1 also allows better visualization of the geographical locations of the analyzed cities. Therefore, regardless of geographic and cultural differences, results show the five analyzed cities presented similar strategies in terms of collaborative governance, placing Copenhagen, London and Barcelona among the results that demonstrate greater ability to involve citizens and to produce public policies with collaboration strategies, while Amsterdam develops strategies to give more transparency for public administration with citizen's involvement and Hamburg with greater focus on producing economic results and green infrastructures with public-private partnerships and with local discussions with people.

\section{The main results}

The results demonstrate that collaborative governance is the key to the development of sustainable cities. It emphasizes that a city can only be sustainable if the governance process allows citizen participation. To exemplify this, I7 highlighted: "In order to have a sustainable city and make it something that is sustainable, in terms of long-lasting, you need the inhabitants to be on your side and participate in an active way. So, I think it cannot become sustainable without actively participating inhabitants". 
The results also show that the involvement and collaboration of people who live or use the city to improve the quality of public policies and help the government to prioritize investments and projects. Likewise, interviewees argued that collaborative governance allows a city to be liveable and it has the capacity to articulate the dimensions of sustainability since consensus-driven decisions shape a plural agenda.

The study points out that a mixed approach to sustainability and governance includes the desire of different organizations and people, recognizing the diversity for a smart governance plan. In this sense, interviewees report that collaborative governance must involve citizens from the planning stage, allowing the construction of a holistic view of the city. In addition, results show that collaborative governance processes should involve stakeholders also in the deliberation process.

We can define collaborative governance as a process of city co-ordination, where government and citizens act in partnership. The results stress that the government can only achieve sustainability and good public policies if it conducts a broad process of collaborative governance. In this sense, collected data emphasize that cities must create strategies to engage their citizens and interest groups in collaborative governance processes.

The results also report that it is necessary to build engagement strategies even on not-so-attractive topics since active participation is the only way to achieve goals. In addition, results show the importance of developing stakeholder maps and intentionally choosing the individuals who will participate in the discussions, seeking to improve the capacity of the discussion results.

In this sense, interviewees from Copenhagen argue that the intentional choice of stakeholders ensures that only entities with real representativeness participate in decision-making processes. They also report that collaborative governance should record and consider all stakeholder suggestions as this enables the creation of integrated solutions.

Interviewees of Amsterdam stressed the importance of the stakeholders involved in the processes of collaborative governance to take responsibility within the decision-making processes, as this avoids the creation of a participatory system where people are free to discuss and decide without any public commitment.

\section{Benefits of collaborative governance}

One of the main reasons that cities adopt models of collaborative governance is the benefit that participation can bring to public policies. In this sense, Figure 2 was elaborated to systematize the main benefits of collaborative governance for cities and sustainability identified in the empirical research. 


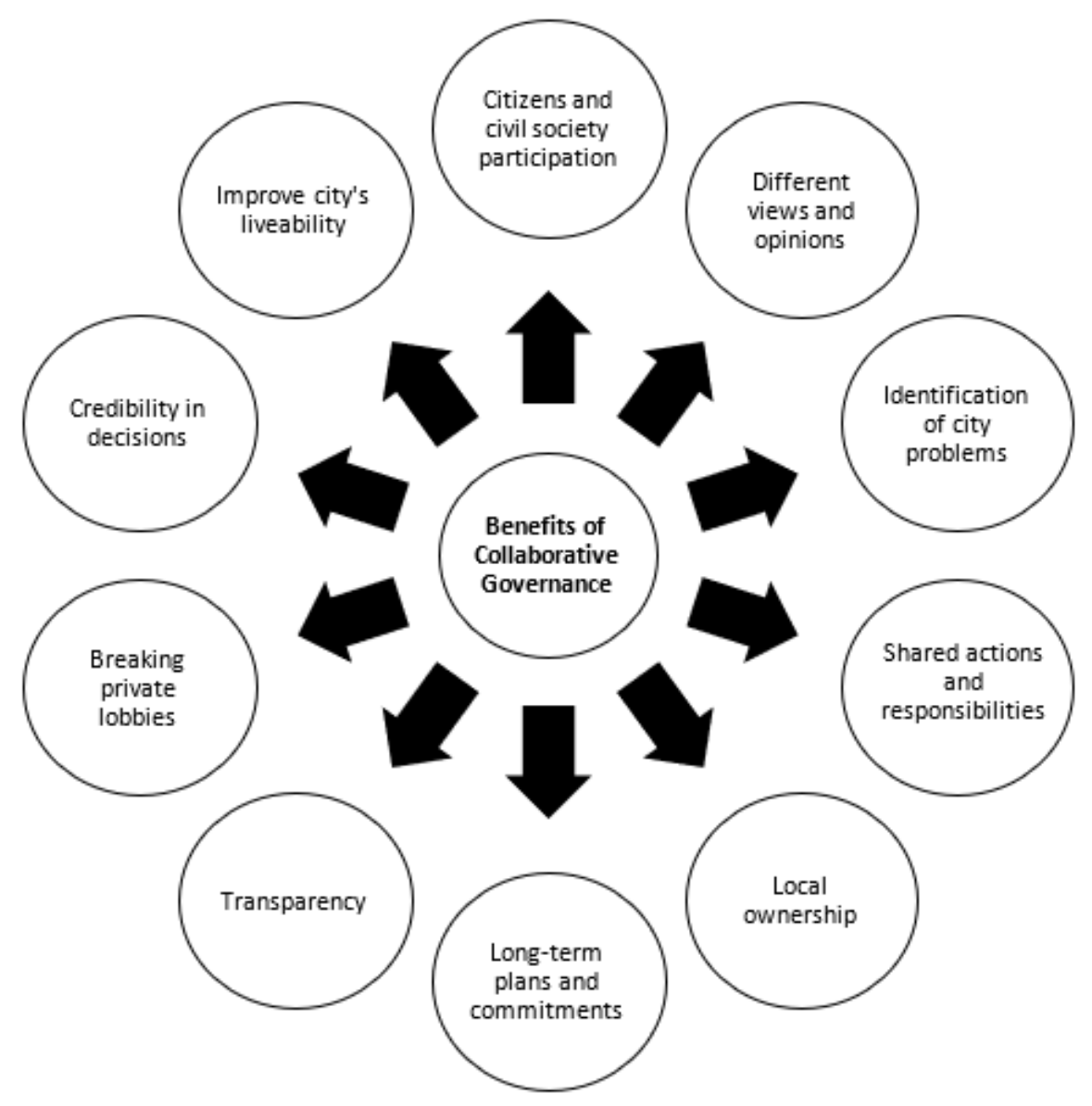

Figure 2 - Benefits of Collaborative Governance. Source: Authors (2019).

Cities that implement collaborative strategies have the capacity to construct public policies based on the contribution of different points of view and social actors, precisely identifying local problems and improving public investment. In addition, it creates the capacity to think in the long term, having as a principle the transparency and the division of responsibilities in the structuring of sustainability policies. Finally, the figure shows that collaborative governance enables the empowerment of citizens, making the city a public space for social participation.

In this context, results show that participation is something cultural and that people have in their spirit the desire to change something and to work together for the city. The collected data reveals that collaborative governance means democracy in action and emphasizes that it is necessary to have a mature democracy to carry out a planning process with good governance. To exemplify this, I3 stressed that "for our climate plan, we had a lot of input from different stakeholder groups, universities, businesses and other parts of society, giving input to different parts of the plan when it was developed. Which was also our idea of getting co-funding as well".

Active democracy requires new governance models, which must be collaborative and produce positive results for the society and for sustainability. Therefore, one interviewee from Barcelona reported that cities seeking to develop collaborative strategies need to create a balanced and socially equitable environment to promote discussions that produce benefits for the community. 


\section{Instruments and mechanisms for collaborative governance}

Interviewees from all analyzed cities reported several instruments and mechanisms used by the local governments to engage people and promote participation, which is key to establishing a collaborative governance system, as shown in Table 2 .

Table 2 - Governance Mechanisms

\begin{tabular}{cc}
\hline Cities & Governance mechanisms \\
\hline Copenhagen & Surveys, Regular Meetings, Opinion Consultation. \\
Amsterdam & Regular Meetings, Thematic Forums, Public Hearings. \\
London & Regular Meetings, Opinion Consultation, Online Surveys, Digital Platforms, Working Groups, \\
Hamburg & Discussion Boards, Public Hearings. \\
Barcelona & Online Surveys, Networks, Discussion Groups. \\
\hline
\end{tabular}

Source: Authors (2019).

The interviewed argue that it is not possible to involve all citizens in face-to-face participatory processes, and it is necessary to use technologies. I15 illustrated this when dealing with the city's infrastructure plan by describing that "city council uses things like Twitter, Facebook, social media and also developing simpler communication materials as well, things like videos on YouTube, like summarized versions of this document". In this sense, the results highlight the importance of using hybrid mechanisms to extend the reach of the tools, conducting governance processes that combine strategies of face-to-face engagement and digital platforms.

The results show that governance arrangements depend on a definition of political leadership, which may give more or less emphasis on collaborative governance. To illustrate this, I25 argued the following: "there has been a change of government, right? Of the city, and a political party that has in its program a lot of participation, consensus, good work, the debate and in that sense, we have expectations, in a positive way, to see what are the real changes". Thus, if there is no legislation that establishes the processes of collaborative governance, the processes may undergo changes at each change of government.

Therefore, interviewed from Copenhagen, Amsterdam and London mentioned the existence of legislation to maintain a minimum of legal requirements to ensure the functioning of collaborative governance systems. I12 illustrates this by arguing that "we have a legal requirement to consult the public, I think a five-week window".

It is also important to stress that collaborative governance requires technical skills and professional structures to be well performed. In this sense, results reinforce that carrying out participatory processes requires financial resources and time and if the city is not willing to provide these resources, it is recommended not to develop collaborative processes, so the outcome of public policy may be poor.

Regarding resources, I4 stressed that "you have to have the time and resources as always and collaboration demands resources. If you're going to interact with people and organizations, you have to put resources into it. You have to put more manpower, more money into it and the hassle, of course, and the good thing, is that you have more output" and I23 said "what is the City Council going to do? Provide all the possible support for everything to happen".

\section{Constraints of collaborative governance}

Stakeholders from all analyzed cities emphasized the importance of transparency for collaborative governance systems, in order to reduce constraints in the processes of collaboration. Considering this context, the research identified constraints related to the systems of collaborative governance, which are demonstrated in Table 3. 
Table 3 - Constraints of collaborative governance

\begin{tabular}{|c|c|}
\hline Limits & Understanding \\
\hline $\begin{array}{l}\text { Discussions focused on self- } \\
\text { interest. }\end{array}$ & $\begin{array}{l}\text { The stakeholders of a collaborative process are willing to discuss only their own } \\
\text { interests and agenda. }\end{array}$ \\
\hline $\begin{array}{l}\text { Demotivation in participatory } \\
\text { processes. }\end{array}$ & $\begin{array}{l}\text { The lack of motivation of the stakeholders to participate in collaborative processes } \\
\text { due to slowness and lack of results. }\end{array}$ \\
\hline $\begin{array}{l}\text { Technical or highly complex } \\
\text { subjects. }\end{array}$ & $\begin{array}{l}\text { The use of consultation with citizens can be ineffective when the issues are technical } \\
\text { or highly complex. }\end{array}$ \\
\hline Difficulty to find solutions. & Stakeholders are able to identify problems but have difficulty in finding solutions. \\
\hline Lack of consensus. & $\begin{array}{l}\text { The lack of consensus could lead policymakers to take a decision, collapsing all the } \\
\text { collaborative governance process. }\end{array}$ \\
\hline $\begin{array}{l}\text { The final decision must be made } \\
\text { by a policy maker. }\end{array}$ & $\begin{array}{l}\text { Collaborative governance should establish processes for collecting opinions, but } \\
\text { the final decision rests with the politician. }\end{array}$ \\
\hline Agenda definitions. & $\begin{array}{l}\text { The political agent defines the agenda to be discussed with the population, not } \\
\text { allowing other topics to be discussed. }\end{array}$ \\
\hline Stakeholders without responsibility. & $\begin{array}{l}\text { Participatory processes have empowered stakeholders with the right to decide, but } \\
\text { not to hold them accountable for the effects of their decisions. }\end{array}$ \\
\hline Lack of financial resources. & $\begin{array}{l}\text { The lack of financial resources to structure the processes of collaborative } \\
\text { governance. }\end{array}$ \\
\hline $\begin{array}{l}\text { Bureaucracies or excessive } \\
\text { regulations. }\end{array}$ & Excessive laws and regulations can hamper collaborative governance processes. \\
\hline Subjects with low attractiveness. & $\begin{array}{l}\text { Subjects with low attractiveness or knowledge of the population can minimize the } \\
\text { number of participants in a discussion. }\end{array}$ \\
\hline $\begin{array}{l}\text { Issues of political interest. } \\
\text { Financial criteria to choose } \\
\text { projects and public policy. }\end{array}$ & $\begin{array}{l}\text { Issues of political interest do not progress in participatory governance processes. } \\
\text { Financial criteria should be taken into account for the choice of projects and public } \\
\text { policies discussed together with the population. }\end{array}$ \\
\hline
\end{tabular}

Source: Authors (2019).

Aiming at good results in collaborative processes, cities should promote an environment conducive to collaboration. Likewise, respondents from all cities argued that good governance is done with collaboration and in a system where all stakeholders and citizens are equal and independent. I12 emphasized that in collaborative processes "everyone must have the same opportunity to contribute". Besides that, results show that communication and feedback are essential to maintaining transparency and the desire for participation in collaborative frameworks.

The results reinforce that personal interests should be left aside and that rules and discussion topics should be clear to everyone from the beginning. I25 argued that "All agents have the same value and therefore equality is real. If everything is spoken openly well it's the issue of transparency".

The study also demonstrates that collaborative governance processes must be consensus-driven, which is a negotiation process. I25 stressed that "between the white and the black there are many shades of gray", being that all contributions are valid. The results demonstrate that consensus building is a process that requires technique and skill, as highlighted by I7 "It's important that you listen to the people and engage in those tiny fights, but it's also very important to strive for the bigger goals and focus on the end game".

\section{Risks and threats of collaborative governance}

The interviewees report that consensus-based decision makes the design of good public policies possible and if the collaborative governance is carried out in an inadequate way or without principles of equality and good governance it places risks and threats to the processes. In this way, based on empirical data, Table 4 was elaborated to demonstrate negative externalities related to the process of collaborative governance. 
Table 4 - Risks and threats of collaborative governance

\begin{tabular}{|c|c|}
\hline Risks & Understanding \\
\hline Frustrations and unfulfilled expecto & $\begin{array}{l}\text { The lack of management or excessive expectation of results by the } \\
\text { stakeholders in a process of participation. }\end{array}$ \\
\hline nts recurrence in discussions & $\begin{array}{l}\text { Meetings and discussions with the recurring presence of the same people or } \\
\text { organizations. }\end{array}$ \\
\hline $\begin{array}{l}\text { The domain } \\
\text { oro }\end{array}$ & $\begin{array}{l}\text { of participatory processes by organizations with power, financial } \\
\text { nd conditions to influence the political agenda. }\end{array}$ \\
\hline Conflict & gotiation pre \\
\hline $\begin{array}{l}\text { A long-term requiremen } \\
\text { making. }\end{array}$ & $\begin{array}{l}\text { Long discussion processes that may require years and decades for decision- } \\
\text { making. }\end{array}$ \\
\hline $\begin{array}{l}\text { Excludes citizens who do not have time } \\
\text { to participate. }\end{array}$ & $\begin{array}{l}\text { Exclusion of citizens and organizations that do not have time to participate in } \\
\text { governance processes. }\end{array}$ \\
\hline $\begin{array}{l}\text { Communication problems and lack of } \\
\text { feedback. }\end{array}$ & Lack of clarity or feedback in the communication process. \\
\hline gults & Emphas \\
\hline A & $\begin{array}{l}\text { The choice of stakeholders favorable to } \mathrm{g} \\
\text { manipulation of participatory processes by stakeho }\end{array}$ \\
\hline $\begin{array}{r}\text { Deformity } \\
\text { dev }\end{array}$ & $\begin{array}{l}\text { r construction of public policies due to the poor design of participatory } \\
\text { es. }\end{array}$ \\
\hline ss. & $\begin{array}{l}\text { Extremist positions and speeches in negotiation processes, not consolidating a } \\
\text { systemic and sustainable vision. }\end{array}$ \\
\hline
\end{tabular}

Source: Authors (2019).

In this context, an interviewed from the City of London argued that for good governance it is mandatory to involve all kinds of stakeholders and allow them to participate in a balanced way. Likewise, an interviewed from Amsterdam reported that good governance is oriented towards participation and sustainability. And, an interviewed from Barcelona said that good governance must look to future generations and establish a path to sustainability.

\section{Long-term plans and sustainability}

The study demonstrates that the establishment of collective long-term plans is fundamental for models of collaborative governance and to improve sustainability at the local level. In this sense, I20 stressed that "we have to think in the long run to be sustainable". Therefore, an interviewed in the city of Hamburg emphasized that the involvement of civil society in long-term plans is important to build a vision beyond the period of political mandates.

The collected data show that all analyzed cities have long-term plans to solve complex problems such as infrastructure issues and global problems such as climate change. Thus, results demonstrate that cities must establish participatory long-term visions to create living conditions for future generations and to be sustainable.

Lastly, interviewed technicians from the city halls of London and Hamburg reported that long-term plans require adaptations throughout their implementation in order for targets to be met, and cities must set short-term goals to maintain stakeholder engagement. In this sense, I10 explained that "It is important to combine this side of the future and this goal to concrete goals every year, then you also need more control on making those goals, because I do see a tendency for people to change the deadline when they realize they can't reach it". 


\section{Conceptual framework}

Based on the empirical evidence, we reached a conceptual framework of collaborative governance, which is described in Table 5. It describes the category of collaborative governance through two subcategories and eight characteristics.

Table 5 - Description of the conceptual framework of collaborative governance

\begin{tabular}{|c|c|c|c|}
\hline Category & Subcategories & Characteristics & Understanding \\
\hline \multirow{6}{*}{$\begin{array}{l}\text { Collaborative } \\
\text { Governance }\end{array}$} & \multirow{4}{*}{$\begin{array}{l}\text { Instruments and } \\
\text { Mechanisms }\end{array}$} & \multirow{2}{*}{$\begin{array}{l}\text { Leadership of the } \\
\text { political agents. } \\
\text { Arrangements and } \\
\text { institutional } \\
\text { aspects. }\end{array}$} & $\begin{array}{c}\text { Influence of political leadership on the levels of } \\
\text { collaborative governance. }\end{array}$ \\
\hline & & & $\begin{array}{l}\text { Legal or institutional aspects that influence the } \\
\text { functioning of a collaborative governance system. }\end{array}$ \\
\hline & & $\begin{array}{l}\text { Professional } \\
\text { Structure. }\end{array}$ & $\begin{array}{c}\text { Professional structure for the creation, coordination, } \\
\text { and articulation of the process of collaborative } \\
\text { governance. }\end{array}$ \\
\hline & & $\begin{array}{l}\text { Interaction and } \\
\text { participation } \\
\text { mechanisms. }\end{array}$ & $\begin{array}{l}\text { Instruments for consultation of opinion and } \\
\text { participation }\end{array}$ \\
\hline & \multirow[t]{2}{*}{$\begin{array}{l}\text { Good } \\
\text { Governance }\end{array}$} & $\begin{array}{l}\text { Ability to } \\
\text { collaborate. } \\
\text { Power balance } \\
\text { and Consensus. }\end{array}$ & $\begin{array}{l}\text { Ability to collaborate and engage different } \\
\text { stakeholders in a process of participation. } \\
\text { Negotiation process among independent } \\
\text { stakeholders in an environment of a balance of } \\
\text { power for the establishment of solutions and } \\
\text { agreements through common sense. }\end{array}$ \\
\hline & & $\begin{array}{l}\text { Long-term vision. } \\
\text { Communication } \\
\text { and Transparency. }\end{array}$ & $\begin{array}{l}\text { at sustainable development with the participation of } \\
\text { society's stakeholders. } \\
\text { Communication processes and required features for } \\
\text { the development of trust. }\end{array}$ \\
\hline
\end{tabular}

Source: Authors (2018).

The conceptual framework is an important result of the research, which conducts this study to the analysis and discussion session.

\section{Analysis and discussion}

The research carried out a series of evidence, which together with the literature, allowed the creation of a prescriptive conceptual framework that aims to explain a relation between collaborative governance and sustainable cities.

The results of the research show a positive relationship between greater collaborative governance and sustainability in the analyzed cities. Based on this relation, two hypotheses related to the collaborative governance of cities were defined and presented in the final remarks.

The presence of two categories of Collaborative Governance was also evident, being referred to here as "Good Governance" and "Instruments and Mechanisms". Thus, Figure 3 shows a relationship between the categories. 


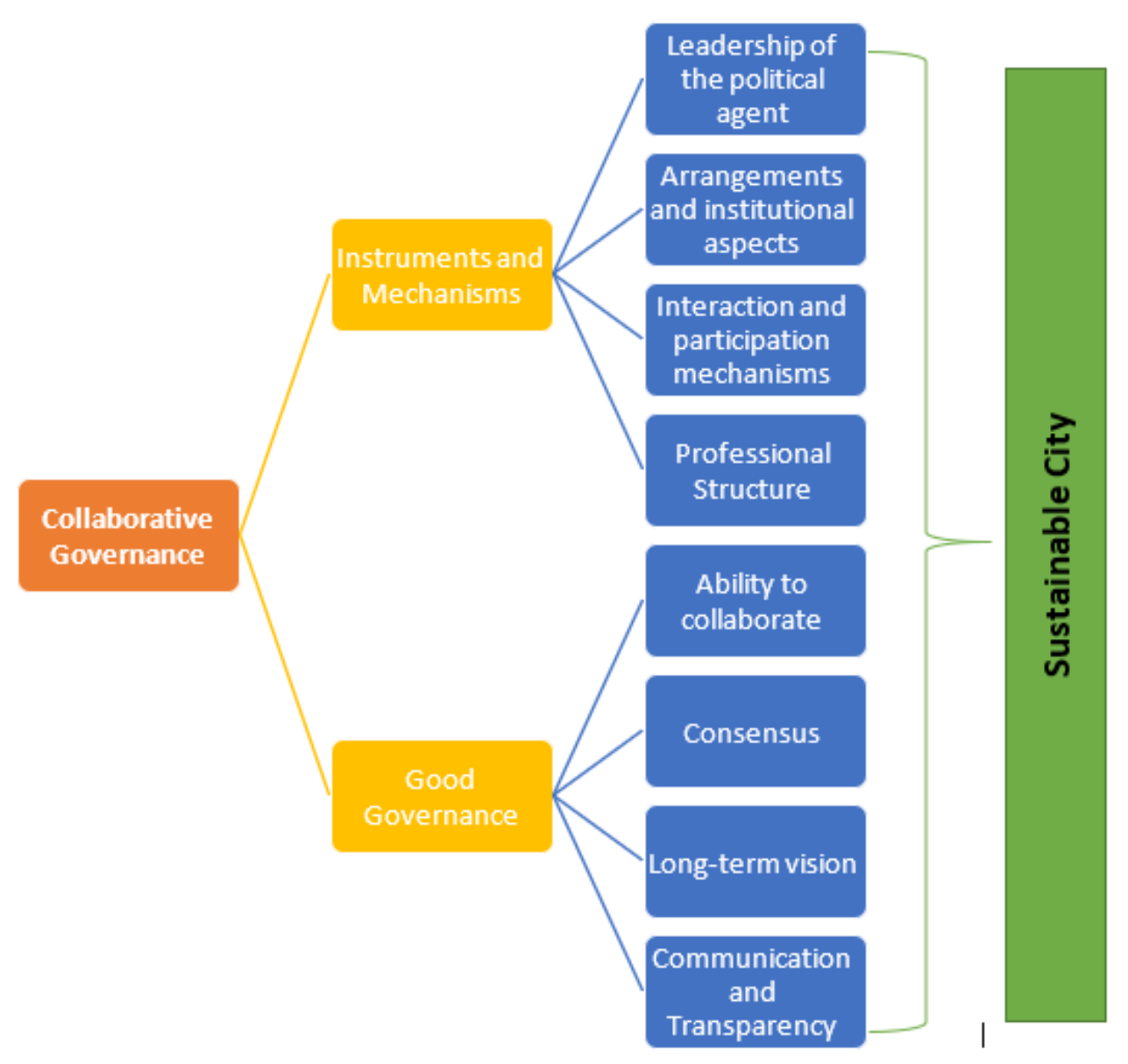

Figure 3 - Conceptual Framework of Collaborative Governance for Sustainable Cities. Source: Authors (2018).

It is important to highlight that the "Good Governance" is recognized here as a normative category since it establishes that values, knowledge, behaviors, attitudes, among others, are necessary for a more effective collaborative governance. The "Instruments and Mechanisms" category presents prescriptive elements, which outline how to institute collaborative governance.

The presented framework prescribes how collaborative governance must be established to move cities toward sustainable development. In addition, it describes how collaborative governance is constituted, using interaction mechanisms and principles of good governance, enabling the creation of a holistic view of the city and the establishment of long-term policies.

As said by Bryson et al. (2014) and Gupta et al. (2015) to materialize sustainability from collaborative governance it is necessary participation of all. In this sense, Ronconi (2011) argues that participatory governance recognizes the excluded people as citizens and generates public spaces for participation and social control. The result is a win-win relationship.

The results of the literature and empirical research indicate that the processes of collaborative governance bring innumerable benefits to the cities, as it enables the creation of a holistic vision of the demands and interests of society. Participatory models can include citizens and stakeholders in different stages - from formulation to decision-making - in the establishment of projects and public policies.

The results show that the analyzed cities have legal mechanisms that allow the participation of society in the public thing, but that the level of use of collaborative governance is influenced by the political leadership. Thus, cities have various tools and mechanisms of interaction to work with the population, which can use face-to-face facilitation techniques and/or digital means in a single or combined way.

According to the arguments of the interviewees, we can say that to ensure effectiveness in collaborative governance different instruments should be used. The collected data shows that the 
selection of the instrument of participation depends on the audience to be involved and the subject to be discussed.

Through the empirical research it is evident that to shape sustainability it is important the use of participatory arrangements and mechanisms to create holistic master plans, climate plans, long-term public policies, as this allows the participation of all citizens - from the poorest to the richest - generating equality, decision-transparency, power balance and the establishment of democracy (Bryson at al., 2014; Gupta et al., 2015; Emerson et al., 2011).

It is important to stress that cities should establish a professional and technical structure - with a defined budget and other resources - for the realization of participatory governance processes, in order to mitigate the various negative externalities that are inherent to the process.

In this way, the research indicates that negative externalities can be mitigated with technical apparatus and principles of good governance. In addition, the collaborative governance systems should create an environment of equality and independence among stakeholders, so that collaboration is facilitated.

Argues that the sustainable development of a city involves the creation of local stakeholder networks, made up of citizens, associations, educational centers, companies, unions, class entities and nongovernmental organizations, in order to add knowledge and experiences in finding solutions to local problems and new public policies (Hawkins \& Wang, 2012; Emerson et al., 2011).

Thus, networks such these can provide technical support to local governments by fostering innovation and strengthening strategies and public policies (Hawkins \& Wang, 2012). In the same way, Krause (2016) argues that partnerships with these characteristics are important for city innovation.

The fundamentals of good governance are based on the principle of transparency, independence, and equality. Cities must develop assertive communication processes in order to maintain the engagement of citizens and all stakeholders. It turns out that this is critical to the success of a collaborative governance system.

It is important to emphasize that the instruments and mechanisms of collaboration must be chosen according to the public and the subject that will be consulted or integrated into the governance process, considering that a sustainable city should guide its decisions by consensus. In this sense, Ansell \& Gash (2007) and Kapucu (2015) said that different from other democratic systems where the opinions of the majority prevail, in systems of participatory governance the orientation is for consensus.

The results also indicate that the lack of consensus in the processes of collaborative governance can hinder decision-making. At this point, the research reveals that in some cases the lack of consensus may indicate that a public policy or decision is not yet mature enough to be made, but that in other cases there must be intervention with the decision from a political agent.

It is clear that the establishment of a collaborative governance model must be able to minimize negative externalities and overcome constraints, in order to allow the elaboration of long-term plans and projects in order to make cities more sustainable and to provide livability for future generations.

\section{Final remarks}

The results of the research demonstrate that collaborative governance is a process that surpasses representative democracy and creates a window for the sustainable development and holistic plans that contemplate the contributions of citizens. This depends on the adoption of a model capable of highlighting the benefits of collaborative governance and of undermining its negative externalities.

The conceptual framework presented is a tool of process recommendations for cities to establish systems of collaborative governance, allowing a balanced development towards sustainability. Thus, two hypotheses related to the collaborative governance of cities were elaborated. The first hypothesis is that the more collaborative the governance model of a city, the more sustainable the city will be. The second 
hypothesis is that the more institutionalized the sustainability practices of a city, the more collaborative the city will be.

The systems of collaborative governance must be constituted with technique, balance of power and transparency. In addition, these systems depend on resources such as time and money for its proper functioning. Thus, cities must establish economic-financial criteria to define subjects, projects, and plans that will use collaborative governance tools.

It is important to emphasize the importance of legal arrangements and institutional aspects, as this can guarantee the functioning of the mechanisms and instruments of collaborative governance in the long term and minimize the dependence of political influence in establishing the level of social participation in city subjects.

In terms of research limitations, it is clear that despite a significant and well-sized sample for a qualitative study, the results of this research cannot be generalized, since cities around the world have a number of different characteristics and cultural aspects.

Therefore, we can conclude that the results of this research aim to broaden the theory of collaborative governance and to propose a framework and list of good practices to speed up the transition of cities towards sustainability.

\section{References}

Amsterdam. Municipality. Department of Urban Planning and Sustainability. (2015). Summary: sustainable Amsterdam. Retrieved in 2018, November 22, from

https://assets.amsterdam.nl/publish/pages/675721/samenvatting_a5_agenda_duurzaamheid_eng.pdf

Ansell, C., \& Gash, A. (2007). Collaborative governance in theory and practice. Journal of Public Administration and Theory, 13, 1-29.

Barcelona. Ayuntamiento de Barcelona. (2015). Ciudad comprometida con el medio ambiente. Retrieved in 2018, November 22, from https://bcnroc.ajuntament.barcelona.cat/jspui/handle/11703/83508

Bartoletti, R., \& Faccioli, F. (2016). Public engagement, local policies, and citizens' participation: an italian case study of civic collaboration. Social Media+ Society, 2(3), 1-11. https://doi.org/10.1177/2056305116662187.

Blanco, I. (2013). Analyzing urban governance networks: bringing regime theory back in theory back in. Environment and Planning. C, Government \& Policy, 31(2), 276-291. http://dx.doi.org/10.1068/c11174.

Boström, M., Jönsson, A. M., Lockie, S., Mol, A. P., \& Oosterveer, P. (2015). Sustainable and responsible supply chain governance: challenges and opportunities. Journal of Cleaner Production, 107, 1-7.

http://dx.doi.org/10.1016/j.jclepro.2014.11.050.

Bryson, J. M., Crosby, B. C., \& Bloomberg, L. (2014). Public value governance: moving beyond traditional public administration and the new public management. Public Administration Review, 74(4), 445-456.

http://dx.doi.org/10.1111/puar.12238.

Bulkeley, H., \& Betsill, M. (2005). Rethinking sustainable cities: multilevel governance and the'urban'politics of climate change. Environmental Politics, 14(1), 42-63. http://dx.doi.org/10.1080/0964401042000310178.

Copenhagen. (2014). Solutions for sustainable cities. Retrieved in 2018, November 22, from https://stateofgreen.com/files/download/1174

Challies, E., Newig, J., Thaler, T., Kochskämper, E., \& Levin-Keitel, M. (2016). Participatory and collaborative governance for sustainable flood risk management: an emerging research agenda. Environmental Science \& Policy, 55(2), 275-280. http://dx.doi.org/10.1016/j.envsci.2015.09.012.

Charmaz, K. (2006). Constructing grounded theory: a practical guide through qualitative research. London: Sage.

Creswell, J. W. (2013). Research design: qualitative, quantitative, and mixed methods approaches (3rd ed., pp. 296). London: SAGE. 
Dallabrida, V. R. (2015). Governança territorial: do debate teórico à avaliação da sua prática. Análise Social, 215, 304-328.

De Oliveira, J. A. P., Doll, C. N., Balaban, O., Jiang, P., Dreyfus, M., Suwa, A., Moreno, P. R., \& Dirgahayani, P. (2013). Green economy and governance in cities: assessing good governance in key urban economic processes. Journal of Cleaner Production, 58, 138-152. http://dx.doi.org/10.1016/j.jclepro.2013.07.043.

Dobbs, R., \& Remes, J. (2013). The shifting urban economic landscape, what does it mean for cities?. Washington: World Bank Group.

Duarte, M. C.S. (2015). 0 direito à cidade e o direito às cidades sustentáveis no Brasil: o direito à produção e fruição do espaço e o enfrentamento do déficit de implementação. Revista FIDES, 6(1), 15-33.

Eisenhardt, K. (1989). Building theory from case study research. Academy of Management Review, 14(4), 532-550. http://dx.doi.org/10.5465/amr.1989.4308385.

Eldridge, K., Larry, L., Baird, J., \& Kavanamur, D. (2018). A collaborative governance approach to improving tertiary education in Papua New Guinea. Asia Pacific Journal of Education, 38(1), 78-90.

http://dx.doi.org/10.1080/02188791.2018.1423949.

Elkington, J. (2006). Governance for sustainability. Corporate Governance, 14(6), 522-529.

http://dx.doi.org/10.1111/j.1467-8683.2006.00527.x.

Emerson, K., \& Nabatchi, T. (2015). Collaborative governance regimes. Washington: Georgetown University Press.

Emerson, K., Nabatchi, T., \& Balogh, S. (2011). An integrative framework for collaborative governance. Journal of Public Administration: Research and Theory, 22(1), 1-29. http://dx.doi.org/10.1093/jopart/mur011.

Filatotchev, I., \& Wright, M. (2017). Methodological issues in governance research: an editor's perspective. Corporate Governance, 25(6), 454-460. http://dx.doi.org/10.1111/corg.12211.

Flick, U. (2008). Designing qualitative research (pp. 120). London: SAGE.

Francis, N., \& Feiock, R. C. (2011). A guide for local government executives on energy efficiency and sustainability. Washington: IBM Center for the Business of Government.

Frey, K. (2004). Governança interativa: uma concepção para compreender a gestão pública participativa? Política \& Sociedade, 3(5), 118-138.

Fukuyama, F. (2013). What is governance? Governance: an International Journal of Policy, Administration and Institutions, 26(3), 347-368. http://dx.doi.org/10.1111/gove.12035.

Glaeser, E., \& Joshi-Ghani, A. (2013). The urban imperative: toward shared prosperity. Washington: World Bank Group.

Gorissen, L., Spira, F., Meynaerts, E., Valkering, P., \& Frantzeskaki, N. (2016). Moving towards systemic change? Investigating acceleration dynamics of urban sustainability transitions in the Belgian City of Genk. Journal of Cleaner Production, 173(1), 171-185.

Gupta, J., Pouw, N. R., \& Ros-Tonen, M. A. (2015). Towards an elaborated theory of inclusive development. European Journal of Development Research, 27(4), 541-559. http://dx.doi.org/10.1057/ejdr.2015.30.

Hamburg. (2016). European Green Capital: 5 years on. Retrieved in 2018, November 22, from http://ec.europa.eu/environment/europeangreencapital/wp-content/uploads/2011/04/Hamburg-EGC-5-YearsOn_web.pdf

Hamilton, M., \& Lubell, M. (2017). Collaborative governance of climate change adaptation across spatial and institutional scales. Policy Studies Journal: the Journal of the Policy Studies Organization, 46(2), 222-247. http://dx.doi.org/10.1111/psj.12224.

Hawkins, C. V., \& Wang, X. (2012). Sustainable development governance: citizen participation and support networks in local sustainability initiatives. Public Works Management \& Policy, 17(1), 7-29.

http://dx.doi.org/10.1177/1087724X11429045. 
Healey, P. (2015). Planning theory: the good city and its governance (2nd ed.). USA: International Encyclopedia of the Social \& Behavioral Sciences. http://dx.doi.org/10.1016/B978-0-08-097086-8.74027-X.

Helms, L. (2016). Democracy and innovation: from institutions to agency and leadership. Democratization, 23(3), 459-477. http://dx.doi.org/10.1080/13510347.2014.981667.

Jannuzzi, P. M. (2017). Indicadores sociais no Brasil: conceitos, fontes de dados e aplicações (6th ed., pp. 1-196). Campinas: Allínea.

Kahn, M. E. (2013). Sustainable and smart cities. Washington: World Bank Group.

Kapucu, N. (2015). Leadership and collaborative governance in managing emergencies and crises. In Fra Paleo U. (Ed.), Risk governance (pp. 211-235). Dordrecht: Springer.

Kirk, J., \& Miller, M. L. (1986). Reliability and validity in qualitative research: qualitative research methods. London: SAGE.

Kissler, L., \& Heidemann, F. G. (2006). Governança pública: novo modelo regulatório para as relações entre Estado, mercado e sociedade?. Revista de Administração Pública, 40(3), 479-499. http://dx.doi.org/10.1590/S003476122006000300008.

Krause, R. M. (2016). Policy innovation, intergovernmental relations, and the adoption of climate protection initiatives by US cities. Journal of Urban Affairs, 33(1), 45-60. https://doi.org/10.1111/j.1467-9906.2010.00510.x.

Lakatos, E. M., \& Marconi, M. D. A. (1992). Ciência e conhecimento científico: metodologia científica. São Paulo: Atlas.

Li, H., \& de Jong, M. (2017). Citizen participation in China's eco-city development. Will 'new-type urbanization'generate a breakthrough in realizing it? Journal of Cleaner Production, 162, 1085-1094. http://dx.doi.org/10.1016/j.jclepro.2017.06.121.

Li, Y., Homburg, V., De Jong, M., \& Koppenjan, J. (2016). Government responses to environmental conflicts in urban China: the case of the Panyu waste incineration power plant in Guangzhou. Journal of Cleaner Production, 134, 354361. http://dx.doi.org/10.1016/j.jclepro.2015.10.123.

London. (2015). Infrastructure plan 2050 update. Retrieved in 2018, November 22, from https://www.london.gov.uk/file/22098/download?token=XZV8z8Az

Marcaletti, F., \& Riniolo, V. (2015). A participatory governance model towards the inclusion of ethnic minorities. An action research experience in Italy. Revue Interventions Économiques, 53.

http://dx.doi.org/10.4000/interventionseconomiques.2609.

Marshall, C., \& Rossman, G.B. (2006). Designing qualitative research (pp. 352). London: SAGE.

Matias-Pereira, J. (2010). Manual de gestão pública contemporânea (3rd ed.). São Paulo: Atlas.

McCormick, K., Anderberg, S., Coenen, L., \& Neij, L. (2013). Advancing sustainable urban transformation. Journal of Cleaner Production, 50, 1-11. http://dx.doi.org/10.1016/j.jclepro.2013.01.003.

Miles, M. B., \& Huberman, A. M. (1984). Qualitative data analysis: a sourcebook of new methods (pp. 263). London: SAGE.

Miranda, R. A. D., \& Amaral, H. F. (2011). Corporate governance and social responsibility management in stateowned enterprises. Revista Administração Pública, 45(4), 1069-1094. http://dx.doi.org/10.1590/S003476122011000400008.

ONU-HABITAT. (2011). Global report on human settlements. Cities and climate change: policy directions (300 p.). Washington: ONU-HABITAT.

Ronconi, L. (2011). Governança pública: um desafio à democracia (public governance: a chanllege to democracy. Emancipação, 11(1), 1-14. http://dx.doi.org/10.5212/Emancipacao.v.11i1.0002.

Ruzzarin; R., \& Siminovschi, M. (2010). Competências, uma base para a governança corporativa. London: AGE.

Saldaña, J. (2016). The coding manual for qualitative researchers (pp. 368). London: SAGE. 
Schwab, K. (2017). The fourth industrial revolution. New Work: Crown Business, Crown Publishing Group New York.

Shark, A. R. (2012). Seven trends that will transform local government through technology (pp. 172). Virginia: Public Technology Institute.

Skelcher, C., Sullivan, H., \& Jeffares, S. (2013). Hybrid governance in european cities. Neighbourhood, migration and democracy (pp. 190). UK: Palgrave Macmillan. http://dx.doi.org/10.1057/9781137314789.

Smith, R., \& Wiek, A. (2012). Achievements and opportunities in initiating governance for urban sustainability. Environment and Planning C: government and Policy, 30, 429-447. https://doi.org/10.1068/c10158.

Streit, R. E., \& Klering, L. R. (2004). Governança pública sob a perspectiva dos Sistemas Complexos. In Encontro de administração pública e governança, Rio de Janeiro: EnAPG.

Van De Meene, S. J., Brown, R. R., \& Farrelly, M. A. (2011). Towards understanding governance for sustainable urban water management. Global environmental change (pp. 1117-1127). USA: Elsevier.

Wachhaus, A. (2013). Governance beyond government. Administration \& Society, 46(5), 573-593.

http://dx.doi.org/10.1177/0095399713513140.

Wargent, M., \& Parker, G. (2018). Re-imagining neighbourhood governance: the future of neighbourhood planning in England. The Town Planning Review, 89(4), 379-402. http://dx.doi.org/10.3828/tpr.2018.23.

World Bank Group. (1992). Global economic prospects and the developing countries (pp. 1-82). Washington: International Economics Department, World Bank Group.

Yi, H., Krause, R. M., \& Feiock, R. C. (2017). Back-pedaling or continuing quietly? Assessing the impact of ICLEI membership termination on cities' sustainability actions. Environmental Politics, 26(1), 138-160.

http://dx.doi.org/10.1080/09644016.2016.1244968.

Yin, R. K. (2005). Estudo de caso: planejamento e metodologia (3rd ed.). Porto Alegre, Brasil: Bookman.

Editor: Janaína Pasqual Lofhagen.

Received: May 01, 2019

Approved: May 07, 2019 